\title{
Methanofollis formosanus sp. nov., isolated from a fish pond
}

Correspondence

Mei-Chin Lai

mclai@dragon.nchu.edu.tw
Sue-Yao Wu, Sheng-Chung Chen and Mei-Chin Lai

Department of Life Sciences, National Chung Hsing University, Taichung, Taiwan, ROC
Based on results of DNA-DNA hybridization and 16S rRNA gene sequence analysis, hydrogenotrophic, irregularly coccoid methanogens of the family Methanomicrobiaceae have been separated into five genera: Methanomicrobium, Methanogenium, Methanoculleus, Methanolacinia and Methanofollis (Bleicher et al., 1989; Blotevogel et al., 1991; Boone et al., 1993; Corder et al., 1983; Jain et al., 1988; Lai \& Chen, 2001; Maestrojuán et al., 1990; Ollivier et al., 1986, 1998; Rivard \& Smith, 1982; Romesser et al., 1979; Rouvière et al., 1992; Widdel, 1986; Widdel et al., 1988; Xun et al., 1989; Zellner et al., 1997, 1998, 1999).

The genus Methanofollis, which includes Methanofollis tationis Chile $9^{\mathrm{T}}$ and Methanofollis liminatans strains GKZPZ $^{\mathrm{T}}$ and BM1, was formally proposed by Zellner et al. (1999) on the basis of 16S rRNA gene sequencing and chemotaxonomic and physiological data. Methanofollis tationis Chile $9^{\mathrm{T}}$ was isolated from a solfataric field on Mount Tatio in the Atacama Desert in northern Chile (Zabel et al., 1984), whereas Methanofollis liminatans $\mathrm{GKZPZ}^{\mathrm{T}}$ and $\mathrm{BM} 1$ were isolated from an industrial wastewater reactor in Germany (Zellner et al., 1990,

Published online ahead of print on 22 October 2004 as DOI 10.1099/ ijs.0.63475-0.

The GenBank/EMBL/DDBJ accession number for the $16 \mathrm{~S}$ rRNA gene sequence of strain $M L 15^{\top}$ is $A Y 186542$.

An EM of strain ML15 ${ }^{\top}$ and graphs showing the effects of temperature, $\mathrm{pH}$ and salinity on growth of strain $\mathrm{ML}^{1} 5^{\top}$ are available as supplementary material in IJSEM Online.
1999). Recently, a novel methanogen isolated from an aquaculture fish pond near Wang-gong, Taiwan, was reported as Methanofollis aquaemaris N2F9704 ${ }^{\mathrm{T}}$ (Lai \& Chen, 2001). These three Methanofollis species are all mesophilic, highly irregular cocci that use $\mathrm{H}_{2} / \mathrm{CO}_{2}$ and formate for growth and methanogenesis. However, Methanofollis aquaemaris $\mathrm{N} 2 \mathrm{~F} 9704^{\mathrm{T}}$ differs from the other strains in its source, substrate utilization, $M_{\mathrm{r}}$ of the S-layer protein subunit, effect of tungsten on growth and optimal ranges of $\mathrm{NaCl}$ and $\mathrm{pH}$ for growth. Moreover, the 16S rRNA gene sequence similarities of Methanofollis aquaemaris $\mathrm{N} 2 \mathrm{~F} 9704^{\mathrm{T}}$ with the other Methanofollis species were 94.7$95.5 \%$ (Lai \& Chen, 2001). In this report, the isolation and characterization of a novel methanogen, strain $\mathrm{ML}^{\mathrm{T}} 5^{\mathrm{T}}$, which was isolated from an aquaculture fish pond in Taiwan, are described; it is proposed that this strain represents a novel species, Methanofollis formosanus sp. nov.

Strain ML15 ${ }^{\mathrm{T}}$ was isolated from a water sample of a marine aquaculture fish pond near Wang-gong, Taiwan, the same sampling site used for isolation of Methanofollis aquaemaris $\mathrm{N} 2 \mathrm{~F} 9704^{\mathrm{T}}$ (Lai \& Chen, 2001). Sea water and ground water were mixed and pumped into a man-made pond to obtain 10-20\% practical salinity units for the mixed cultivation of Chanos chanos (white mullet) and Meretrix lusoria (Lai et al., 1999). Sampling, enrichment and isolation methods for strain $\mathrm{ML}^{\mathrm{T}}{ }^{\mathrm{T}}$ were according to Lai \& Chen (2001). The modified anaerobic technique of Hungate was performed (Balch et al., 1979; Sowers \& Noll, 1995) and sterilized media were prepared under an oxygen-free $\mathrm{N}_{2}: \mathrm{CO}_{2}(4: 1)$ atmosphere. The composition and preparation of $\mathrm{MB}$ medium 
was as described previously (Lai \& Chen, 2001). MB/W medium was $\mathrm{MB}$ medium with tungstate $\left(\mathrm{Na}_{2} \mathrm{WO}_{4}\right.$, $0.3 \mathrm{mg} \mathrm{l}^{-1}$ ). Minimal medium (MM) was MB medium without the addition of yeast extract and tryptone.

Enrichment was begun immediately after the sample was brought to the laboratory. Strain $\mathrm{ML}^{\mathrm{T}} 5^{\mathrm{T}}$ was isolated and purified as described previously (Lai \& Chen, 2001; Lai et al., 2002 , 2004). Samples (5 ml) from sediments of the marine water aquaculture fish pond were inoculated into a bottle of MB medium (45 ml) containing methanol as methanogenic substrate. The production of methane was determined by GC with flame-ionization detection (Lai et al., 1999). After 1 month incubation at room temperature, methanogenesis occurred and, after four successive transfers, the methanogenic culture was then inoculated into roll-tube $\mathrm{MB} / \mathrm{W}$ agar medium for further isolation. Under the fluorescent microscope, a fluorescence-positive colony with a small opaque centre and irregular translucent margin was picked and transferred to $5 \mathrm{ml} \mathrm{MB} / \mathrm{W}$ medium with methanol in the Coy anaerobic chamber. The culture grew poorly, but good growth was observed after it was further transferred to $\mathrm{MB} / \mathrm{W}$ medium with formate as substrate. Methane-producing cultures from this single colony were further purified by combining the serial dilution method $\left(10^{-4}\right)$, antibiotic tetracycline $\left(100 \mu \mathrm{g} \mathrm{ml}^{-1}\right)$ and roll tube method until contamination by nonmethanogens was not detectable. This isolate, strain $\mathrm{ML}^{\mathrm{T}}{ }^{\mathrm{T}}$, was previously known as N2M9705.

Cells of strain $\mathrm{ML}^{\mathrm{T}} 5^{\mathrm{T}}$ were non-motile, irregular cocci, $1 \cdot 5-2 \cdot 0 \mu \mathrm{m}$ in diameter and stained Gram-negative. Under the phase-contrast microscope (Olympus $\mathrm{BH}-2$ ), the irregular coccus cells appeared with a dark centre surrounded by a transparent outer layer. Refractive areas were observed in the cells. As observed by SEM ABT-150S (sample preparation as described by Lai et al., 1999), strain $M L 15^{T}$ presented irregular flat, disc-shaped cells with concavity (Fig. 1) and planes of division were frequently detected. Cells lysed rapidly in the presence of SDS $\left(0 \cdot 1 \mathrm{~g} \mathrm{l}^{-1}\right)$, indicating that the cell envelope consisted of a protein surface layer (Boone \& Whitman, 1988). The proteinaceous cell wall structure of strain ML15 ${ }^{\mathrm{T}}$ was very sensitive to physical forces, such as those exerted by centrifugation and pipetting, and lysed easily. Negative staining of strain $\mathrm{ML}^{\mathrm{T}} \mathrm{T}^{\mathrm{T}}$ was performed as described previously (Lai \& Shih, 2001) and cells observed under TEM (JEM-200cx; JEOL) showed a hexagonally arranged pattern of S-layer protein (see Supplementary Fig. A available in IJSEM Online). The centre-to-centre spacing of the morphological units of the S-layer lattice of strain $M L 15^{\mathrm{T}}$ was about $16 \cdot 4 \mathrm{~nm}$. Surface-layer proteins were isolated according to the protocol of König (1995). SDS-PAGE was performed as described by Laemmli (1970) and Coomassie blue R-250 was used to visualize protein. Analysis of the S-layer indicated it was composed of a protein subunit with an $M_{\mathrm{r}}$ of 138800 .

Strain $M L 15^{\mathrm{T}}$ is a strictly anaerobic organism; no growth

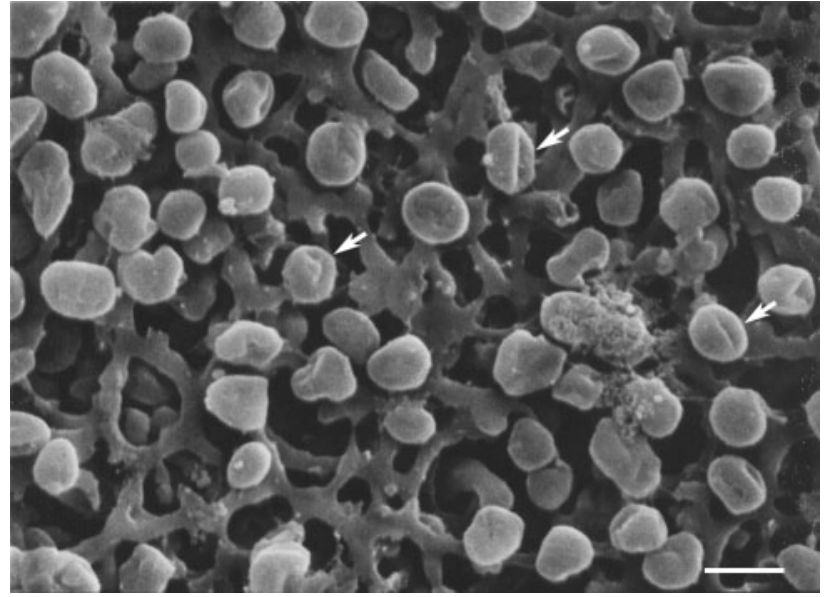

Fig. 1. SEM of strain $M L 15^{\top}$ showing the disc-shaped irregular coccoid cells. Arrows show the division plane of cells. Bar, $1 \cdot 0 \mu \mathrm{m}$.

was observed at low oxygen levels. Under $\mathrm{N}_{2} / \mathrm{CO}_{2}$ atmospheres, strain $\mathrm{ML}^{\mathrm{T}}{ }^{\mathrm{T}}$ grew in $\mathrm{MB} / \mathrm{W}$ medium supplemented with $\mathrm{H}_{2}(100 \%, 200 \mathrm{kPa})$ or sodium formate (100 $\mathrm{mM})$, but not in $\mathrm{MB} / \mathrm{W}$ medium supplemented with sodium acetate $(50 \mathrm{mM})$, trimethylamine $(40 \mathrm{mM})$, methanol $(50 \mathrm{mM})$, ethanol $(48 \mathrm{mM})$, 2-propanol (48 $\mathrm{mM})$, iso-butanol $(48 \mathrm{mM})$, 2-butanol $(48 \mathrm{mM})$ or dimethylamine $(40 \mathrm{mM})$. Specific growth rates were calculated from methane production, which was analysed by linear regression of the logarithm of the total amount of methane that accumulated over time. Inocula were grown under conditions similar to the experimental conditions. The specific growth rate of strain $\mathrm{ML} 15^{\mathrm{T}}$ in $\mathrm{MB} / \mathrm{W}$ medium (containing yeast extract, tryptone and tungsten) with formate $(50 \mathrm{mM})$ plus acetate $(20 \mathrm{mM})$ was $0.019 \mathrm{~h}^{-1}$ (generation time $36 \mathrm{~h}$ ). However, no growth was observed in $\mathrm{MM} / \mathrm{W}$, thus showing the heterotrophic nature of strain $\mathrm{ML}^{\mathrm{T}}{ }^{\mathrm{T}}$. Addition of acetate $(20 \mathrm{mM})$ shortened the lag period, but did not affect the specific growth rate, indicating that acetate was not required for growth of strain $M L 15^{\mathrm{T}}$. Addition of tungsten greatly promoted the cell growth rate, from $0.0096 \mathrm{~h}^{-1}$ in $\mathrm{MB}$ to $0.0191 \mathrm{~h}^{-1}$ in tungsten-containing $\mathrm{MB} / \mathrm{W}$ medium.

The optimal growth parameters of strain $\mathrm{ML} 15^{\mathrm{T}}$ were tested using cells grown in $\mathrm{MB} / \mathrm{W}$ medium with formate plus acetate. Strain $\mathrm{ML} 15^{\mathrm{T}}$ could grow at $25-42^{\circ} \mathrm{C}$ and optimal growth was observed at $40^{\circ} \mathrm{C}$. Temperatures below $20^{\circ} \mathrm{C}$ or above $50^{\circ} \mathrm{C}$ completely inhibited growth of cells (Supplementary Fig. B). Strain $\mathrm{ML}_{15} 5^{\mathrm{T}}$ grew at $\mathrm{pH} 5 \cdot 6-7 \cdot 3$, with optimal growth at $\mathrm{pH} 6 \cdot 6-7 \cdot 0$ (Supplementary Fig. B). At $\mathrm{pH}$ values greater than $7 \cdot 7$, cell growth was completely inhibited suggesting that cells are sensitive to an alkaline environment. Cells of strain $\mathrm{ML}^{\mathrm{T}}{ }^{\mathrm{T}}$ could tolerate $\mathrm{NaCl}$ concentrations of $0-4 \%$, but not above $6 \%$. The optimal $\mathrm{NaCl}$ concentration for growth of strain $\mathrm{ML} 15^{\mathrm{T}}$ was $3 \%$, with a doubling time of $20 \mathrm{~h}$ (Supplementary Fig. B). 
The sensitivity of strain $\mathrm{ML}^{\mathrm{T}} 5^{\mathrm{T}}$ to ampicillin, penicillin G, spectinomycin, kanamycin, tetracycline and chloramphenicol (each at a concentration of $100 \mu \mathrm{g} \mathrm{ml}^{-1}$ ) was tested in $\mathrm{MB} / \mathrm{W}$ medium with sodium formate $(100 \mathrm{mM})$ plus acetate $(20 \mathrm{mM})$ and $0.5 \% \mathrm{NaCl}$ at $37^{\circ} \mathrm{C}$. Results indicated that strain $M L 15^{\mathrm{T}}$ was resistant to ampicillin, penicillin, kanamycin and spectinomycin and sensitive to chloramphenicol; tetracycline inhibited cell growth.

The melting temperatures of DNA from Methanofollis aquaemaris $\mathrm{N} 2 \mathrm{~F} 9704^{\mathrm{T}}$ and strain $\mathrm{ML} 15^{\mathrm{T}}$ were obtained as described previously (Jan et al., 1999; Lai et al., 2004; Marmur \& Doty, 1962) and were 93.52 and $93.25^{\circ} \mathrm{C}$, respectively. The DNA G+C contents of Methanofollis aquaemaris $\mathrm{N} 2 \mathrm{~F} 9704^{\mathrm{T}}$ and strain $\mathrm{ML}^{\mathrm{T}}{ }^{\mathrm{T}}$ were $59 \cdot 07$ and $58 \cdot 41 \mathrm{~mol} \%$, respectively.

For phylogenetic analysis, DNA was isolated by the general procedure of Jarrell et al. (1992). Approximately $30 \mathrm{ng}$ DNA was used as a template for PCR amplification of an approximately 1300 bp portion of the $16 \mathrm{~S}$ rRNA gene. PCR amplification primers used were forward primer coccus 1 $\left(5^{\prime}\right.$-CGACTAAGCCATGCGAGTC- $\left.3^{\prime}\right)$ and reverse primer reverse 3 ( $5^{\prime}$-GTGACGGGCGGTGTGTGCAAG- $\left.3^{\prime}\right)$. The sequences were checked by the program CHECK-PROBE from the Ribosomal Database Project (Maidak et al., 1996) and corresponded to positions 23-41 and 1327-1309 in the 16S rRNA nucleotide sequence of Methanofollis aquaemaris N2F9704 ${ }^{\mathrm{T}}$ (AF262035). As well as the two amplification primers, two additional primers were used for sequencing: shih2 (5'-CGATTACAGGGTTTCACTCCTACC-3') and primer follis 1 (5'-TAATCGGTACGGGTTGTG-3') (Methanofollis aquaemaris N2F9704 ${ }^{\mathrm{T}}$, accession number AF262035, sequence positions 506-482 and 124-141, respectively). The resulting sequence of strain $M L 15^{\mathrm{T}}$ was assembled to produce an approximately 1287 base contiguous rRNA gene sequence (positions 22-1308). Gene sequences of the archaea used were obtained from the Ribosomal Database Project and GenBank. The similarity matrix was obtained based on the analytical results of the Ribosomal Database Project (http://rdp.cme.msu.edu/html/). Multiple sequence alignments were analysed using the package CLUSTAL_W at the Biology Workbench (http:// workbench.sdsc.edu/). Distances were computed with the package CLUSTAL TREE at the same website using the neighbour-joining model and fed to DRAWGRAM in the program package PHYLIP version 3.5c (Felsenstein, 1993). Bootstrap confidence analysis was performed with SEQBOOT of the PHYLIP package using 1000 replicates.

The $16 \mathrm{~S}$ rRNA gene sequence $\left(1287 \mathrm{nt}\right.$ ) of strain ML15 ${ }^{\mathrm{T}}$ was determined and phylogenetic trees were constructed using a selection of sequences from related methanogens obtained from the GenBank database (Fig. 2). 16S rRNA gene sequence similarities between strain $\mathrm{ML} 15^{\mathrm{T}}$ and other members of the families Methanocorpusculaceae, Methanomicrobiaceae and Methanoplanaceae were 85, 91-96 and $91 \%$, respectively. $16 \mathrm{~S}$ rRNA gene sequence analysis placed strain $\mathrm{ML}^{2} 5^{\mathrm{T}}$ close to Methanofollis aquaemaris N2F9704 ${ }^{\mathrm{T}}$

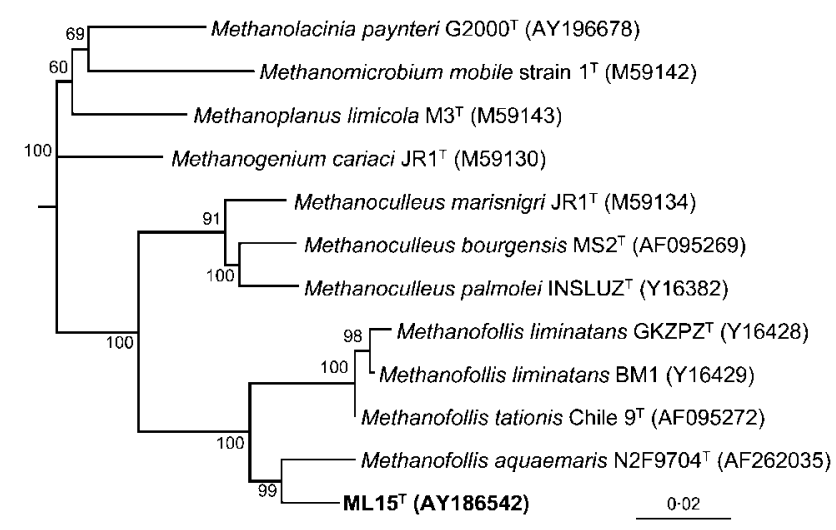

Fig. 2. Phylogenetic analysis of $16 \mathrm{~S}$ rRNA gene sequences showing the relationship between strain $M L 15^{\top}$ and various methanogens. The significance of each branch is indicated by bootstrap percentages. Accession numbers for reference species are shown in parentheses. Bar, 0.02 evolutionary distance.

(sequence similarity 97.2\%), Methanofollis liminatans GKZPZ $^{\mathrm{T}}(95 \cdot 5 \%)$ and Methanofollis tationis Chile $9^{\mathrm{T}}$ $(96 \cdot 3 \%)$.

Strain ML15 ${ }^{\mathrm{T}}$ belongs to the archaeal domain on the basis of envelope composition, metabolism, resistance to antibiotics and 16S rRNA gene sequence (Woese et al., 1990). Devereux et al. (1996) and Fry et al. (1991) have proposed that a similarity of less than $98 \%$ in a $16 \mathrm{~S}$ rRNA sequence is evidence for separate species. The closest relative to strain $\mathrm{ML}^{\mathrm{T}}{ }^{\mathrm{T}}$ was Methanofollis aquaemaris strain $\mathrm{N} 2 \mathrm{~F} 9704^{\mathrm{T}}$ at $97 \cdot 2 \%$ similarity; Methanofollis liminatans $\mathrm{GKZPZ}^{\mathrm{T}}$ (sequence similarity $95.5 \%$ ) and Methanofollis tationis Chile $9^{\mathrm{T}}$ (sequence similarity $96 \cdot 3 \%$ ) were also closely related. The 16S rRNA gene sequence similarity of strain $\mathrm{ML}^{\mathrm{T}}{ }^{\mathrm{T}}$ to the other members of the Methanomicrobiales was $85-93 \%$. Characteristics that differentiate strain $\mathrm{ML}^{2}{ }^{\mathrm{T}}$ from related Methanofollis species are listed in Table 1. These phylogenetic, phenotypic and physiological distinctions indicate that strain $\mathrm{ML} 15^{\mathrm{T}}$ represents a novel Methanofollis species, for which the name Methanofollis formosanus sp. nov. is proposed.

The genus Methanofollis includes Methanofollis tationis Chile $9^{\mathrm{T}}\left(=\mathrm{DSM} 2702^{\mathrm{T}}\right)$, Methanofollis liminatans strains GKZPZ $^{\mathrm{T}}\left(=\mathrm{DSM} 4140^{\mathrm{T}}\right)$ and BM1 (=DSM 10196) (Zellner et al., 1999) and Methanofollis aquaemaris strain $\mathrm{N} 2 \mathrm{~F} 9704^{\mathrm{T}}$ (Lai \& Chen, 2001). All these organisms are mesophilic, highly irregularly cocci that use $\mathrm{H}_{2} / \mathrm{CO}_{2}$ and formate for growth and methanogenesis. Although strain $\mathrm{ML}^{\mathrm{T}}{ }^{\mathrm{T}}$ shares these traits with Methanofollis species, it differs from these species in its source, mobility, substrate utilization and requirements, halotolerance, alkali tolerance, $M_{\mathrm{r}}$ of S-layer protein subunits, growth in the presence of tungsten and phylogenetics (Table 1). Strain $\mathrm{ML}^{\mathrm{T}} 5^{\mathrm{T}}$ and Methanofollis aquaemaris strain $\mathrm{N} 2 \mathrm{~F} 9704^{\mathrm{T}}$ were isolated 
Table 1. Characteristics of Methanofollis species and strain $\mathrm{ML}^{\top} 5^{\top}$

Taxa: 1, strain $\mathrm{ML}^{\mathrm{T}}{ }^{\text {(data from this study); 2, M. aquaemaris N2F9704 }}{ }^{\mathrm{T}}$ (Lai \& Chen, 2001); 3, M. tationis Chile $9^{\mathrm{T}}$ (Zabel et al., 1984); 4, M. liminatans GKZPZ ${ }^{\mathrm{T}}$ (Zellner et al., 1990); 5, M. liminatans BM1 (Zellner et al., 1999). ND, Not determined.

\begin{tabular}{|c|c|c|c|c|c|}
\hline Characteristic & 1 & 2 & 3 & 4 & 5 \\
\hline Cell size $(\mu \mathrm{m})$ & $1 \cdot 5-2 \cdot 0$ & $1 \cdot 2-2 \cdot 0$ & $1 \cdot 5-3 \cdot 0$ & $1 \cdot 25-2 \cdot 0$ & $1 \cdot 25-2 \cdot 0$ \\
\hline Flagella & - & - & + & + & ND \\
\hline S-layer subunit $M_{\mathrm{r}}\left(\times 10^{-3}\right)$ & $138 \cdot 8$ & 137 & 120 & 118 & ND \\
\hline Lattice constant $\mathrm{c} / \mathrm{c}(\mathrm{nm})^{*}$ & $16 \cdot 4$ & 11 & ND & $15 \cdot 4$ & ND \\
\hline Substrates $\dagger$ & $\mathrm{H}, \mathrm{F}$ & $\mathrm{H}, \mathrm{F}$ & $\mathrm{H}, \mathrm{F}$ & $\mathrm{H}, \mathrm{F}, 2 \mathrm{P}, 2 \mathrm{~B}$ & $\mathrm{H}, \mathrm{F}, 2 \mathrm{P}, 2 \mathrm{~B}$ \\
\hline \multicolumn{6}{|l|}{ Temperature for growth $\left({ }^{\circ} \mathrm{C}\right)$ : } \\
\hline Optimum & 40 & 37 & 37 & 40 & 40 \\
\hline Range & $20-42$ & $20-43$ & $25-45$ & $25-45$ & $20-45$ \\
\hline Optimum pH & $6 \cdot 6$ & $6 \cdot 5$ & $7 \cdot 0$ & $7 \cdot 0$ & $7 \cdot 0$ \\
\hline \multicolumn{6}{|c|}{$\mathrm{NaCl}$ concentration for growth (\%): } \\
\hline Optimum & 3 & $0 \cdot 5$ & $0 \cdot 8-1 \cdot 2$ & ND & ND \\
\hline Range & $0-6$ & $0-6$ & $0-7$ & $0-2 \cdot 9$ & ND \\
\hline Tungsten requirement $\ddagger$ & S & s & $\mathrm{R}$ & s & s \\
\hline Acetate requirement $\neq$ & s & S & $\mathrm{R}$ & $\mathrm{R}$ & $\mathrm{R}$ \\
\hline $\mathrm{G}+\mathrm{C}$ content $(\mathrm{mol} \%)$ & $58 \cdot 4$ & $59 \cdot 1$ & $54 \cdot 0$ & $59 \cdot 3$ & $60 \cdot 0$ \\
\hline Source & Aquaculture fish pond & Aquaculture fish pond & Solfataric field & Wastewater reactor & Wastewater reactor \\
\hline
\end{tabular}

${ }^{\star}$ Centre-to-centre spacing of hexagonally arranged protein subunits of the S-layer.

$\dagger \mathrm{H}, \mathrm{H}_{2} / \mathrm{CO}_{2}$; F, formate; $2 \mathrm{P}, 2$-propanol $/ \mathrm{CO}_{2} ; 2 \mathrm{~B}, 2$-butanol $/ \mathrm{CO}_{2}$.

$\ddagger \mathrm{R}$, Required; S, growth stimulated.

from the same source (aquaculture fish pond) and, morphologically, they are very similar, non-motile irregular cocci, unlike Methanofollis tationis and Methanofollis liminatans, which were motile with flagella. Cells of members of the family Methanomicrobiaceae have hexagonal S-layer lattices consisting of glycoprotein subunits with $M_{\mathrm{r}}$ of 101 000-155000 (Zellner et al., 1999). All Methanofollis species possess surface layer proteins as a cell envelope, forming a soft bag for the cells. The $M_{\mathrm{r}}$ of the S-layer protein subunits from ML15 ${ }^{\mathrm{T}}$ and Methanofollis aquaemaris strain N2F9704 ${ }^{\mathrm{T}}$ were 138800 and 137000 , respectively; $M_{\mathrm{r}}$ of the S-layer protein subunits for Methanofollis tationis and Methanofollis liminatans were around 120000 . Also, both strain $\mathrm{ML}^{\mathrm{T}} 5^{\mathrm{T}}$ and Methanofollis aquaemaris strain $\mathrm{N} 2 \mathrm{~F} 9704^{\mathrm{T}}$ could only use formate and $\mathrm{H}_{2} / \mathrm{CO}_{2}$ as catabolic substrates, could not utilize 2-propanol/ $\mathrm{CO}_{2}$ or 2-butanol/ $\mathrm{CO}_{2}$ and did not require acetate for cell growth, although it could reduce the lag time. In contrast, both Methanofollis tationis and Methanofollis liminatans required acetate for cell growth and $M$. liminatans could use 2-propanol/ $\mathrm{CO}_{2}$ and 2-butanol/ $/ \mathrm{CO}_{2}$ to produce methane.

Within the order Methanomicrobiales, the growth requirement for tungsten has been reported in Methanoculleus palmolei (Zellner et al., 1998) and Methanofollis tationis (Zabel et al., 1984). No growth was observed in Methanofollis tationis, an organism isolated from a solfataric field, if tungsten was not present in the growth medium (Zabel et al., 1984). In contrast, growth of the related organisms Methanofollis liminatans, isolated from effluent of a wastewater reactor (Zellner et al., 1990, 1999), Methanocalculus chunghsingensis, from an estuarine environment (Lai et al., 2002), and Methanofollis aquaemaris and strain $\mathrm{ML}^{1} 5^{\mathrm{T}}$, from an aquaculture fish pond (Lai et al., 2004 and this study), was greatly stimulated by tungsten, but the element was not absolutely required for growth. In the case of the estuarine isolate Methanocalculus taiwanensis $\mathrm{P} 2 \mathrm{~F} 9704 \mathrm{a}^{\mathrm{T}}$, the trace element tungsten was not required, but it slightly stimulated growth and could extend the growth range relating to temperature, $\mathrm{pH}$ and salt concentration (Lai \& Chen, 2001).

All known Methanofollis species are mesophilic and neutrophilic. However, the $\mathrm{pH}$ range for growth of strain $\mathrm{ML} 15^{\mathrm{T}}$ was $\mathrm{pH} 5 \cdot 6-7 \cdot 3$ and cell growth was completely inhibited at $\mathrm{pH} 7 \cdot 7$, indicating that this strain is more sensitive to an alkaline environment than other species. Also, the optimal salt $(\mathrm{NaCl})$ concentration for growth of strain $\mathrm{ML} 15^{\mathrm{T}}$ was $3 \%$, which is the highest concentration observed in Methanofollis species. Phylogenetic (Fig. 2), phenotypic and physiological distinctions (Table 1) between Methanofollis species suggest that these species form two clusters, with M. aquaemaris and strain $\mathrm{ML}^{\mathrm{T}}{ }^{\mathrm{T}}$ constituting one cluster. The 16S rRNA gene sequence similarities of Methanofollis aquaemaris and strain $\mathrm{ML}^{\mathrm{T}} 5^{\mathrm{T}}$ to Methanofollis liminatans $\mathrm{GKZPZ}^{\mathrm{T}}$ were within the range $95 \cdot 3-96 \cdot 3 \%$. 


\section{Description of Methanofollis formosanus sp. nov.}

Methanofollis formosanus (for.mo.sa'nus. N.L. masc. adj. formosanus from Formosa, the beautiful island of Taiwan).

Irregularly coccoid cells, non-motile, $1 \cdot 5-2 \cdot 0 \mu \mathrm{m}$ in diameter. Obligately anaerobic cells. Stains Gram-negative. Cell wall has an SDS-sensitive S-layer protein with an $M_{\mathrm{r}}$ of 138800 . Catabolic substrates used include $\mathrm{H}_{2} / \mathrm{CO}_{2}$ and formate, but not acetate, methanol, trimethylamine, dimethylamine, ethanol, 2-propanol, iso-butanol, 2-butanol or dimethylamine. Cells are mesophilic and grow at 20$42{ }^{\circ} \mathrm{C}$, with optimal growth at $37^{\circ} \mathrm{C}$. Cells grow at $\mathrm{pH} 5 \cdot 6$ $7 \cdot 3$, with optimal growth at $\mathrm{pH} 6 \cdot 6$. Cells grow well in $0-4 \%$ $\mathrm{NaCl}$, with optimal growth at $3 \% \mathrm{NaCl}$. Addition of acetate reduces the lag time and the trace element tungsten greatly promotes cell growth and extends the growth range. No growth is detected in minimal medium. Growth is completely inhibited by chloramphenicol and partly inhibited by tetracycline, but not by ampicillin, penicillin, kanamycin or spectinomycin. The $\mathrm{G}+\mathrm{C}$ content of DNA of strain $\mathrm{ML}^{15} 5^{\mathrm{T}}$ is $58 \cdot 4 \mathrm{~mol} \%$.

The type strain is strain $\mathrm{ML}^{\mathrm{T}}\left(=\mathrm{OCM} 789^{\mathrm{T}}=\mathrm{DSM}\right.$ $\left.15483^{\mathrm{T}}\right)$, isolated from a marine water aquaculture fish pond near Wang-gong, Taiwan.

\section{Acknowledgements}

The author would like to thank Ming-Jen Chuang, Tong-Yung Hong, Chia-Chi Liu, Li-Jane Lai and Chi-Ming Shu for help in sampling and enrichment. The technical assistance of Ms Pei-Chi Chao and Yen-Shiun Lin (electron microscopy) from the Regional Instruments Center and the laboratory of Dr S. H. Chou $(\mathrm{G}+\mathrm{C}$ content determination) at the Biochemistry Institute, National Chung Hsing University, were greatly appreciated. This work was supported in part by grant NSC 93-2621-B-005-004 from the National Council of Science, Taiwan, Republic of China.

\section{References}

Balch, W. E., Fox, G. E., Magrum, L. J., Woese, C. R. \& Wolfe, R. S. (1979). Methanogens: re-evaluation of a unique biological group. Microb Rev 43, 260-296.

Bleicher, K., Zellner, G. \& Winter, J. (1989). Growth of methanogens on cyclopentanol/ $/ \mathrm{CO}_{2}$ and specificity of alcohol dehydrogenase. FEMS Microbiol Lett 59, 307-312.

Blotevogel, K.-H., Gahl-Janßen, R., Janssen, S., Fischer, U., Pilz, F., Auling, G., Macario, A. J. L. \& Tindall, B. J. (1991). Isolation and characterization of a novel mesophilic, fresh-water methanogen from river sediment Methanoculleus oldenburgensis sp. nov. Arch Microbiol 157, 54-59.

Boone, D. R. \& Whitman, W. B. (1988). Proposal of minimal standards for describing new taxa of methanogenic bacteria. Int J Syst Bacteriol 38, 212-219.

Boone, D. R., Whitman, W. B. \& Rouvière, P. (1993). Diversity and taxonomy of methanogens. In Methanogenesis, pp. 35-80. Edited by J. G. Ferry. New York, NY: Chapman \& Hall.

Corder, R. E., Hook, L. A., Larkin, J. M. \& Frea, J. I. (1983). Isolation and characterization of two new methane-producing cocci:
Methanogenium olentangyi, sp. nov., and Methanococcus deltae, sp. nov. Arch Microbiol 134, 28-32.

Devereux, R., He, S.-H., Doyle, C. L., Orkland, S., Stahl, D. A., LeGall, J. \& Whitman, W. B. (1996). Diversity and origin of Desulfovibrio species: phylogenetic definition of a family. J Bacteriol 172, 3609-3619.

Felsenstein, J. (1993). PHYLIP (phylogenetic inference package), version 3.5c. Department of Genetics, University of Washington, Seattle, WA, USA.

Fry, N. K., Warwick, S., Saunders, N. A. \& Embley, T. M. (1991). The use of $16 \mathrm{~S}$ ribosomal RNA analyses to investigate the phylogeny of the Legionellaceae. J Gen Microbiol 137, 1215-1222.

Jain, M. K., Bhatnagar, L. \& Zeikus, J. G. (1988). A taxonomic overview of methanogens. Indian J Microbiol 28, 143-177.

Jan, R.-L., Wu, J., Chaw, S.-M., Tsai, C.-W. \& Tsen, S.-D. (1999). A novel species of thermoacidophilic archaeon, Sulfolobus yangmingensis sp. nov. Int J Syst Bacteriol 49, 1809-1816.

Jarrell, K. F., Faguy, D., Hebert, A. M. \& Kalmokoff, M. L. (1992). A general method of isolating high molecular weight DNA from methanogenic archaea (archaebacteria). Can J Microbiol 38, 65-68.

König, H. (1995). Isolation and analysis of cell walls from methanogenic Archaea. In Archaea: a Laboratory Manual, vol. 2, Methanogens, pp. 315-328. Edited by K. R. Sowers \& H. T. Schreier. Cold Spring Harbor, NY: Cold Spring Harbor Laboratory.

Laemmli, U. K. (1970). Cleavage of structural proteins during the assembly of the head of bacteriophage T4. Nature 227, 680-685.

Lai, M.-C. \& Chen, S.-C. (2001). Methanofollis aquaemaris sp. nov., a methanogen isolated from an aquaculture fish pond. Int J Syst Evol Microbiol 51, 1873-1880.

Lai, M.-C. \& Shih, C.-J. (2001). Characterization of Methanococcus voltaei strain P2F9701a: a new methanogen isolated from estuarine environment. Curr Microbiol 42, 432-437.

Lai, M.-C., Shu, C.-M., Chiou, M.-S., Hong, T.-Y., Chuang, M.-J. \& Hua, J. J. (1999). Characterization of Methanosarcina mazei strain N2M9705 isolated from an aquaculture fishpond. Curr Microbiol 39, 79-84.

Lai, M.-C., Chen, S.-C., Shu, C.-M. \& 7 other authors (2002). Methanocalculus taiwanensis sp. nov., isolated from an estuarine environment. Int J Syst Evol Microbiol 52, 1799-1806.

Lai, M.-C., Lin, C.-C., Yu, P.-H., Huang, Y.-F. \& Chen, S.-C. (2004). Methanocalculus chunghsingensis sp. nov., isolated from an estuary and a marine fishpond in Taiwan. Int J Syst Evol Microbiol 54, 183-189.

Maestrojuán, G. M., Boone, D. R., Xun, L., Mah, R. A. \& Zhang, L. (1990). Transfer of Methanogenium bourgense, Methanogenium marisnigri, Methanogenium olentangyi, and Methanogenium thermophilicum to the genus Methanoculleus gen. nov., emendation of Methanoculleus marisnigri and Methanogenium and description of new strains of Methanoculleus bourgense and Methanoculleus marisnigri. Int J Syst Bacteriol 40, 117-122.

Maidak, B. L., Olsen, G. J., Larsen, N., Overbeek, R., McCaughey, M. J. \& Woese, C. R. (1996). The Ribosomal Database Project (RDP). Nucleic Acids Res 24, 82-85.

Marmur, J. \& Doty, P. (1962). Determination of the base composition of deoxyribonucleic acid from its thermal denaturation temperature. J Mol Biol 4, 109-118.

Ollivier, B. M., Mah, R. A., Garcia, J. L. \& Boone, D. R. (1986). Isolation and characterization of Methanogenium bourgense sp. nov. Int J Syst Bacteriol 36, 297-301.

Ollivier, B., Fardeau, M.-L., Cayol, J.-L., Magot, M., Patel, B. K. C., Prensier, G. \& Garcia, J.-L. (1998). Methanocalculus halotolerans 
gen. nov., sp. nov., isolated from an oil-producing well. Int J Syst Bacteriol 48, 821-828.

Rivard, C. J. \& Smith, P. H. (1982). Isolation and characterization of a thermophilic marine methanogenic bacterium, Methanogenium thermophilicum sp. nov. Int J Syst Bacteriol 32, 430-436.

Romesser, J. A., Wolfe, R. S., Mayer, F., Spiess, E. \& WaltherMauruschat, A. (1979). Methanogenium, a new genus of marine methanogenic bacteria, and characterization of Methanogenium cariaci sp. nov. and Methanogenium marisnigri sp. nov. Arch Microbiol 121, 147-153.

Rouvière, P., Mandelco, L., Winker, S. \& Woese, C. R. (1992). A detailed phylogeny for the Methanomicrobiales. Syst Appl Microbiol 15, 363-371.

Sowers, K. R. \& Noll, K. M. (1995). Techniques for anaerobic growth. In Archaea: a Laboratory Manual, vol. 2, Methanogens, pp. 15-48. Edited by K. R. Sowers \& H. T. Schreier. Cold Spring Harbor, NY: Cold Spring Harbor Laboratory.

Widdel, F. (1986). Growth of methanogenic bacteria in pure culture with 2-propanol and other alcohols as hydrogen donors. Appl Environ Microbiol 51, 1056-1062.

Widdel, F., Rouviere, P. E. \& Wolfe, R. S. (1988). Classification of secondary alcohol-utilizing methanogens including a new thermophilic isolate. Arch Microbiol 150, 477-481.

Woese, C. R., Kandler, O. \& Wheelis, M. L. (1990). Towards a natural system of organisms: proposal for the domains Archaea, Bacteria and Eucarya. Proc Natl Acad Sci U S A 87, 4576-4579.
Xun, L., Boone, D. R. \& Mah, R. A. (1989). Deoxyribonucleic acid hybridization study of Methanogenium and Methanocorpusculum species, emendation of the genus Methanocorpusculum, and transfer of Methanogenium aggregans to the genus Methanocorpusculum as Methanocorpusculum aggregans comb. nov. Int J Syst Bacteriol 39, 109-111.

Zabel, H. P., König, H. \& Winter, J. (1984). Isolation and characterization of a new coccoid methanogen, Methanogenium tationis spec. nov. from a solfataric field on Mount Tatio. Arch Microbiol 137, 308-315.

Zellner, G., Sleytr, U. B., Messner, P., Kneifel, H. \& Winter, J. (1990). Methanogenium liminatans spec. nov., a new coccoid, mesophilic methanogen able to oxidize secondary alcohols. Arch Microbiol 153, 287-293.

Zellner, G., Conway de Macario, A. J. L. \& Conway de Macario, E. (1997). A study of three anaerobic methanogenic bioreactors reveals that syntrophs are diverse and different from reference organisms. FEMS Microbiol Ecol 22, 295-301.

Zellner, G., Messner, P., Winter, J. \& Stackebrandt, E. (1998). Methanoculleus palmolei sp. nov., an irregularly coccoid methanogen from an anaerobic digester treating wastewater of a palm oil plant in North-Sumatra, Indonesia. Int J Syst Bacteriol 48, 1111-1117.

Zellner, G., Boone, D. R., Keswani, J., Whitman, W. B., Woese, C. R., Hagelstein, A., Tindall, B. J. \& Stackebrandt, E. (1999). Reclassification of Methanogenium tationis and Methanogenium liminatans as Methanofollis tationis gen. nov., comb. nov. and Methanofollis liminatans comb. nov. and description of a new strain of Methanofollis liminatans. Int J Syst Bacteriol 49, 247-255. 